\title{
AN EMPIRICAL INVESTIGATION OF ALLIANCE PORTFOLIO STRATEGIES OF MEDIUM AND LARGE COMPANIES OPERATING IN ROMANIA
}

\author{
Cosmin Florin LEHENE ${ }^{a^{*}}$ \\ a Babeș-Bolyai University - Alumni, Romania
}

\begin{abstract}
In this paper we have investigated the alliance portfolio strategies of best performers medium and large companies operating in Romania. Adapting, shaping, and stabilizing alliance portfolio strategies were investigated based on an existent theoretical framework, but extending the criteria used to evaluate each type. Based on a qualitative and quantitative analysis of the answers provided by 46 companies we found divergent patterns of adoption of alliance portfolio strategies by companies in our sample. From the 46 companies considered in our study 16 implemented a shaping alliance portfolio strategy. Thus, these companies used alliances to shape the environment according to company's strategy. In addition, 17 companies implemented an adapting alliance portfolio strategy using alliances to adapt, respectively 13 companies resorted to a stabilizing alliance portfolio strategy using alliances to stabilize their environment. At molecular level, we found that most of medium size firms resorted to an adapting alliance portfolio strategy (11 companies) while most of large companies appealed to a shaping alliance portfolio strategy (15 companies). We also found that most MNC resorted to alliances either to shape or stabilize the environment as part of their strategy in Romania. Using alliances to adapt to their environment as part of their strategy was mostly used by Romanian companies. Moreover, we found that all companies operating in a younger industry resorted to a shaping alliance portfolio strategy, while for those operating in more mature industries the patterns were more diverse and equilibrated. For all these variables the alliance portfolio strategies were also separated investigated in detail. The findings in this paper might have implications for international business and strategic management scholars, particularly those studying strategy topics in Eastern Europe.
\end{abstract}

KEYWORDS: alliance portfolio strategy, large firms, $M N C$, strategic alliances.

DOI: 10.24818/IMC/2021/03.01

\section{INTRODUCTION}

In the recent decades, strategic alliances became an ubiquitous phenomena in the business arena, capturing the attention of both management scholars and practitioners (Gulati, 1998). Even though the alliances grew in importance in the last three, four decades, their existence is as old as the existence of organizations (Lehene, 2020). What is new is the fact that only recently the companies have understood that modern competition takes place more often between alliances (dyads) and networks of alliances (clusters) and less often between individual companies (Porter, 1998; 2003). The modern global competition forces the companies to engage in the international arena together with a trustful group of partners, rather than going alone. This strategy is called by some scholars octopus' strategy (Vyas et al., 1995), collaborative strategy (Barnes et al., 2012; Hitt et al., 2007) or alliance strategy (Hoffmann, 2005; 2007).

\footnotetext{
*Corresponding author. E-mail address: lehenecosmin@ymail.com
} 
In general terms, the research conducted in the field of strategic alliances aims to better understand the phenomena of collaboration between organizations at two different levels of analysis: the dyad/alliance level (Dyer \& Singh, 1998; Gulati, 1998; Hatfield et al., 1998; Taylor, 2005) and the portfolio level - all the alliances/collaborations of a focal firm (de Leeuw et al., 2014; Dyer et al., 2001; Heimericks et al., 2009; Hoffmann, 2005; 2007). In the focus of this paper are all the alliances and partnerships of a focal firm, therefore, the portfolio of alliances. Many ideas have been developed recently in relation with firms' portfolio of alliances. For instance, the relationship between portfolio of alliances and firm's performance (Collins \& Riley, 2013; Sarkar et al., 2009), the diversity of partners within the portfolio (Collins \& Riley, 2013; de Leeuw et al., 2014), or how the companies can manage their portfolio of alliances (Hoffmann, 2005).

Even though these advancements in the alliance management literature, regarding the understanding and explanation of behavior of companies in respect to their portfolio of alliances, up to now, there is little evidence regarding the strategies the companies use in order to manage their alliances and partnerships. This is the main goal in this paper: to identify the strategies adopted by companies operating in Romania for managing and coordinating all their strategic alliances as a portfolio. This theoretical construct is called Alliance Portfolio Strategy (APS) [Hoffmann, 2005; 2007] and will be defined and discussed next. On the other hand, at least at our awareness, in the alliance management literature there is no evidence regarding the APS of MNC and best performers national companies operating in Eastern Europe. Thus, in this paper we aim to find answer to the following questions: What type of alliance portfolio strategy use the best performers companies and organizations in Romania? Do they use adapting, shaping or stabilizing alliance portfolio strategies? Do the best performers companies operating in Romania always use alliances to shape their environment?

The paper might be valuable for both alliance management scholars and practitioners. First, for alliance academics community the paper might help to better understand the contingency factors which influence/cause the configuration or adoption of a specific APS. At the same time, the results might bring into the attention of researchers studying strategy topics in Eastern Europe the patterns of collaboration of best performers medium and large companies operating in Romania. Second, for management practitioners the paper might be important since provides them useful guidance for designing a strategy for the portfolio of strategic alliances of their company. In addition, managers might find in this paper detailed descriptions of possible alliance portfolio strategies designed and implemented by companies, together with their specific characteristics.

The remainder of the paper continues as follows. First, we start with developing the theoretical constructs/criteria based on which we will identify then the APS of companies in our study. Then, we present the research methodology adopted in this paper. We continue with analyzing the data and discussing the main findings. The paper ends with the conclusions.

\section{LITERATURE REVIEW}

\subsection{Alliance portfolio strategy}

Strategic alliances are regarded as the voluntary collaboration between two or more organizations which put in common some of their resources and competences in order to achieve competitive advantage and superior performances (Albers et al., 2016; Das \& Teng, 2000; Dyer et al., 2001; Gulati \& Singh, 1998; Kale et al., 2002). The companies participate in many strategic alliances, for various motives. Rarely the companies and organizations participate in a single collaboration (Klijn et al., 2010). All these partnerships, collaborations and alliances of a company constitute firm's portfolio of alliances. A main gap in the alliance management literature is the lack of evidence regarding what strategies do the companies use to manage their portfolio of alliances. Thus, what types of APS use the companies to manage all their strategic alliances. 
Following other researchers (Collins \& Riley, 2013; Hoffmann, 2005, 2007; Sarkar et al., 2009; Vapola et al., 2010) we have employed a definition of APS such as an integrated set of actions aiming to design, implement and monitor a portfolio of alliances of a focal firm and the allocation of resources to accomplish firm's goals with alliances. There are basically three types of alliance portfolio strategies: 1) reactively adapting to environment, 2) actively shaping the environment according to firm's strategy, and 3) stabilizing the environment in order to avoid further organizational change (Hoffmann, 2007). Even though we used the typology of APS developed previously within the literature and we have maintained some ideas, we have also adapted these APS to the purposes of our paper. Thus, our view of APS it is a little different. Our view of APS will be described in the following paragraphs.

There are many contingency factors influencing the configuration of APS. For instance, the shaping potential and strategic uncertainty were considered by Hoffmann (2007). The number of alliances and redundancy between alliances (Dyer et al., 2001; Hoffmann, 2005), international strategy (Vapola et al., 2010), or strategic orientation (Lehene, 2017; Nielsen \& Gudergan, 2012; Rothaermel \& Deeds, 2004) were also thought to be factors which influence the configuration of a strategy for the alliance activity. Thus, building upon the existent findings in the alliance literature we have tried to identify/illustrate the APS of companies in our sample based on four criteria/theoretical constructs: Alliance Portfolio Diversity (APD), Shaping Potential (SP), Industry Life Cycle (ILC) and Organizational Life Cycle (OLC). Next, we are going to develop and discuss these four criteria/theoretical constructs and how they influence (or even cause) the designing of a company's APS. Then, starting from these criteria/variables, in the empirical part, we are going to proceed to the identification of APS of companies in our sample.

\subsection{Determinants of alliance portfolio strategy}

The first criteria/theoretical construct used in this study to identify the APS is the diversity of partners with which a company collaborates. According to recent studies is required the collaboration with different type of partners - known such as Alliance Portfolio Diversity (APD) for different types of performances. For example, de Leeuw et al. (2014) found that for better productivity-related performances the companies need to collaborate with very few partners. Normally, these companies collaborate only vertically with firm's suppliers and customers. On the other hand, for radical innovation performances, the portfolio needs to incorporate more partners and be more diverse than for productivity-related performances. Finally, for better incremental innovation performances the scholars observed that companies need to collaborate with the broadest set of alliance partners, including firm's competitors and complementors.

Other studies, for instance Collins \& Riley (2013), examined the relationship between APD and firm's performance. The authors found a curvilinear relationship (inverted -U relationship) between APD and firm's performance. Initially, the performance of firms (measured as ROA) increased as the portfolio of partners became more diverse. But, after a certain point, as the portfolio of partners became more diverse, was observed that the performance was decreasing. In addition, reciprocity was found to positively moderate the relationship between APD and firm's performance, while the status similarity negatively moderated the same relationship.

Next, we have applied the same rationale to identify the APS of companies and organizations. Thus, one company having developed many alliances with firm's suppliers and customers, collaborating with many of organization's competitors and complementors - thus, collaborating intensively both vertically and horizontally - we conceptualize such as having developed an adapting alliance strategy. These companies look to adapt to the existent environment since they might not have enough power to shape or stabilize the environment. In order to better adapt, in addition to productivity, they need to continuously improve their goods and services offered to customers. This action will require collaborating with all possible firms and organizations. Therefore, the alliance 
strategic orientation of these companies is productivity and incremental innovation. These companies only collaborate for this main purposes.

Other company, collaborating with firm's suppliers and customers, plus having developed rather few/particularized alliances and partnerships with some complementors and/or competitors, we conceptualize that is has designed and implemented a shaping alliance strategy. This type of companies since, in general, are powerful companies, in addition to typical vertical collaborations for better productivity, they develop also horizontally collaborations but with very few and preferentially competitors and complementors. The main reason for doing so is to take advantage of new opportunities in order to radically innovate. For instance, they collaborate for a NPD. Thus, the alliance strategic orientation of companies pursuing a shaping alliance portfolio strategy is productivity and radical innovation.

Finally, a company having developed only vertical collaborations with firm's suppliers and customers, or one which collaborates vertically and has developed very few horizontal collaborations we conceptualize that is an organization which has developed a stabilizing alliance strategy. These companies look to stabilize the environment in order to prevent further organizational change, to take advantage of the existing resources and abilities and set industry's standards for operations. The alliance strategic orientation for the companies pursuing a stabilizing alliance portfolio strategy is productivity.

In terms of alliance type - whether exploration or exploitation - the adapting and shaping alliance strategies are simultaneously exploitation and exploration alliance strategies (hybrid/ambidextrous alliance strategies). The differences between the two are that the former alliance strategy entails only incremental innovation (incremental exploration alliance strategy), while the latter aims mainly for radical innovation (radical exploration alliance strategy). For the stabilizing alliance strategy there is the case of an exploitation alliance strategy.

The second criteria/theoretical construct we can use in order to capture the existent APS of companies is conceptualized such as the 'Shaping Potential'. The Shaping Potential (SP) in the context of alliance strategies was also investigated by other researchers. For instance, Hoffmann (2007) described a company's SP in terms of its endowment with resources and abilities. The companies endowed with valuable technical, commercial, and social capital is said to have high SP (Barney \& Clark, 2007; Hoffmann, 2007). In this paper we refer to a company's SP in terms of 1) endowment with resources and abilities - as previous researchers did - and 2) if there was the case of an industry leader. We argue that in the case of industry leaders the SP is also high because of the development of critical resources (e.g. the position of company in the inter-organizational network) and because the company might have accumulated technical or administrative abilities to shape the environment according to its strategy (Barney \& Clark, 2007; David, 2007/2013; Hitt et al., 2007). In this rationale, a low SP will lead the companies to design and implement an adapting or stabilizing alliance strategy. Instead, a high SP will determine the companies to design and implement a shaping alliance strategy.

The third criteria/theoretical construct which can be used to identify the APS is known within management or marketing fields such as the Industry Life Cycle (ILC). The ILC, used sometimes interchangeably with the concept of Product Life Cycle (PLC) [Rice \& Galvin, 2006], is described such as a succession of four evolutionary phases throughout a product/industry passes during its development, starting with 'birth', 'growth', 'maturity' and then 'decline' (Hitt et al., 2007; Hynes \& Wilson, 2012; Rice \& Galvin, 2006). In line with other studies (Vyas et al., 1995), we approach the concept 'industry' in terms of younger or more mature/stable industries since it is very hard to objectively appreciate the current state of development of a certain industry (Hitt et al., 2007).

This criterion might be important for the ideas developed in our study since in younger or more mature/stable industries there are different types of alliance strategies needed to be designed and implemented by companies (Lehene, 2016; Vyas et al., 1995). For example, it has been suggested that in the growth stage of an industry the companies might form contractual alliances, which will 
then evolve, as the industry evolves, towards more knowledge-based alliances and alliances formed to set the industry's standards for operations (Rice \& Galvin, 2006). At the same time, the companies and firms activating in younger industries is thought to mainly form alliances to create/facilitate technological innovations, to share risks and costs, while those operating in latter stages of ILC will collaborate mainly for efficiency seeking, to create diversified product offering and for product refinement (Hynes \& Wilson, 2012; Lehene, 2016; Rice \& Galvin, 2006). Thus, we conceptualize that in the case of companies activating in younger industries they will design and implement shaping alliance strategies, while those operating in more mature/stable industries will tend to implement adapting or stabilizing alliance strategies. Of course, depending also to other factors (e.g. their shaping potential).

The fourth criteria/theoretical construct which can be used to identify the APS is the Organizational Life Cycle (OLC). According to Daft (2010), Hwang and Park (2006; 2007), Lehene (2016), depending to OLC there are different opportunities for alliance formation. For instance, it was thought that while a firm in its birth stage might be looking for partners which might facilitate the access to the necessarily capital to assure its survival, a firm in the middle stage might be searching for manufacturing or marketing alliances to produce or commercialize its products (Hwang \& Park, 2006; 2007).

Given the analogy of living beings postulated in the co-evolutionary theory (Hynes \& Wilson, 2012) and the theory of organizational development (Daft, 2010), we have applied the same rationale in our study. Thus, an entrepreneurial or small firm (1-49 employees) can be classified such as being in its birth stage of OLC. A medium firm (50-249 employees) has all the characteristics of a growth stage firm. Finally, a firm within which work more than 250 employees can be classified such as a mature/stable firm (Lehene, 2016; 2020). Of course, there are many other characteristics of firms depending to their stage of development. For instance, the different degrees of existence of formal rules and procedures. These characteristics are well-known and sufficiently described in organization theory (Daft, 2010), to do not enter in detail in this paper. Also, there might be some limitations regarding the typology above. For example, a company might be formed just five years ago, be an important player in its industry, have employed already 2.000 employees, while an incumbent firm, founded 20-25 years ago might never exceeded the growth stage.

In this rationale, we conceptualize that a company in its birth stage will tend to design and implement an adapting alliance strategy, because of the lack of resources and abilities (low SP). In turn, the firms in their growth stage will tend to design and implement an adapting or stabilizing alliance strategy, considering also other factors (e.g. ILC, SP). For instance, in the case of lack of $\mathrm{SP}$, or in the case the SP is low, the firms will not have enough resources to implement a shaping alliance strategy. Finally, in the case of companies and organizations which are in their maturity stage all three alliance portfolio strategies are suitable for design and implementation.

\subsection{Types of alliance portfolio strategy}

Based on the discussion above the following three types of APS were developed to be evaluated in the empirical part (see also Table 1):

Adapting alliance portfolio strategy: the alliance strategic orientation of companies having designed and implemented an adapting alliance portfolio strategy is productivity and incremental innovation. On the one hand, these companies use exploitation alliances for taking advantage of their base of existing resources and capabilities and on the other hand, they use exploration alliances in order to access new resources and competences, in order to improve company's operations or their goods and services offered to costumers. In addition to typical vertical collaborations with firm's suppliers and customers, the companies pursuing an adapting alliance portfolio strategy have developed many collaborations with horizontal partners (competitors and/or complementors). More specifically, these companies collaborate intensively with all types of partners, vertically and horizontally. The shaping potential of these companies is normally low since in many cases they have not enough 
resources or abilities, or they are not an industry leader. The entrepreneurial and SMEs are typically the types of companies pursuing adapting alliance portfolio strategies but can be also the case of some large companies.

Shaping alliance portfolio strategy: the alliance strategic orientation of companies having designed and implemented a shaping alliance portfolio strategy are productivity and radical innovation. These companies use alliances for exploitation of firm's resources and capabilities and alliances for exploration, but for the identification of new business opportunities, and/or the development of new products. In addition to normal vertical collaborations with firm's suppliers and customers, these companies have developed rather few/preferential horizontal collaborations (with competitors and/or complementors), in comparison with the companies pursuing adapting alliance portfolio strategies. Typically, the companies implementing shaping alliance portfolio strategies have a high shaping potential (e.g. they are subsidiaries of powerful MNC and/or in many cases they are industry leaders). The large companies (organizations more stable which arrived at organizational maturity) are the most probable types of companies designing and implementing shaping alliance portfolio strategies. Shaping alliance portfolio strategies are normally used by companies operating in younger or more mature/stable industries which have high potential for returns on investments.

Stabilizing alliance portfolio strategy: the alliance strategic orientation of companies which have designed and implemented a stabilizing alliance portfolio strategy is productivity. Therefore, these companies use alliances for exploitation of firm's resources and capabilities. The companies pursuing stabilizing alliance portfolio strategies normally, are not interested to innovate (or at least innovation is not the main goal), or they innovate through other means (e.g. Direct Investments, M\&As). The shareholders of these companies are more short-term oriented and look for financial gains, at least for some markets. Since the main goal is productivity - optimization of production and the use of resources - within the alliance portfolio of these companies there are very few/no horizontal partners (competitors and/or complementors). Stabilizing alliance portfolio strategies are normally used by large companies in order to control the environment, prevent further organizational change and set the industry's standards for operations. The shaping potential of companies using this alliance strategy is medium or high and normally this APS is used by companies and firms operating in latter stages of ILC.

Table 1. Criteria/theoretical constructs used to evaluate/identify the APS

\begin{tabular}{|c|c|c|c|}
\hline $\begin{array}{c}\text { APS } \\
\text { Criteria }\end{array}$ & $\begin{array}{l}\text { Adapting alliance } \\
\text { portfolio strategy }\end{array}$ & $\begin{array}{l}\text { Shaping alliance } \\
\text { portfolio strategy }\end{array}$ & $\begin{array}{l}\text { Stabilizing alliance } \\
\text { portfolio strategy }\end{array}$ \\
\hline $\begin{array}{c}\text { Alliance Strategic } \\
\text { Orientation } \\
\text { (main purpose) } \\
\end{array}$ & $\begin{array}{c}\text { productivity }+ \\
\text { incremental innovation }\end{array}$ & $\begin{array}{c}\text { productivity + radical } \\
\text { innovation }\end{array}$ & productivity \\
\hline Alliance type & $\begin{array}{l}\text { exploitation }+ \\
\text { incremental exploration }\end{array}$ & $\begin{array}{c}\text { exploitation + radical } \\
\text { exploration }\end{array}$ & exploitation \\
\hline $\begin{array}{l}\text { Alliance Portfolio } \\
\text { Diversity (APD) }\end{array}$ & $\begin{array}{c}\text { many vertical alliances } \\
+ \text { many horizontal } \\
\text { collaborations }\end{array}$ & $\begin{array}{l}\text { vertical alliances }+ \text { rather } \\
\text { few/preferential } \\
\text { horizontal collaborations }\end{array}$ & $\begin{array}{c}\text { only vertical alliances, } \\
\text { or vertical alliances + } \\
\text { very few horizontal } \\
\text { collaborations } \\
\end{array}$ \\
\hline Shaping Potential (SP) & low & high & low \\
\hline $\begin{array}{c}\text { Industry Life Cycle } \\
\text { (ILC) }\end{array}$ & $\begin{array}{c}\text { more mature/stable } \\
\text { industry }\end{array}$ & younger industry & $\begin{array}{c}\text { more mature/stable } \\
\text { industry }\end{array}$ \\
\hline $\begin{array}{l}\text { Organizational Life } \\
\text { Cycle (OLC) }\end{array}$ & $\begin{array}{c}\text { birth, growth, and } \\
\text { maturity/stability stages }\end{array}$ & maturity/stability stages & $\begin{array}{c}\text { growth and } \\
\text { maturity/stability } \\
\text { stages }\end{array}$ \\
\hline
\end{tabular}

Source: authors' own elaboration based on the cited references 
It is important to mention that the framework described above is generalist in nature, there are patterns of APS rather than fixed frames. For example, a company implementing a shaping alliance portfolio strategy might also develop some preoccupations for the development of incremental innovations. But the idea is that the main purpose for designing and implementing strategic alliances is different. The main purpose for firm's alliance activity in this case is productivity and radical innovation (not incremental innovation).

Another important mention is that no single criteria/theoretical construct can be used to capture/describe the complexity of the APS. Thus, we have evaluated the APS integrating all four criteria/theoretical constructs. Given the discussion above, next, in the empirical part, we are going to analyze the data according to the theoretical framework developed above.

\section{RESEARCH METHODOLOGY}

\subsection{Research strategy}

The research strategy used in this paper is secondary data analysis, in the sense that we used some items from a questionnaire used in a previous study, but for other purposes and combining the items in different theoretical constructs. The main advantage of secondary data analysis is that facilitates the researchers to use the answers provided by respondents, no matter/independently the goal of the present research (Chelcea, 2007). Thus, following other researchers (Brannen, 1996), we have employed a qualitative analysis (a qualitative appreciation) of quantitative answers provided by managers of a sample of best performers medium and large companies operating in Romania. Consequently, the main purpose in this study is theory testing through qualitative and quantitative data analysis. We'd like to mention that the main goal is not to put the theory against the rigor of statistical tests but rather to describe/illustrate the APS according to data provided by managers, according to the theoretical framework developed in the first part of the paper.

The data analyzed in this study was collected using a questionnaire which was administered through email, between October 2017 - March 2018. We have contacted the best performers 785 medium and large companies in Romania, depending to their revenues, from which decided to participate 46 companies (leading to a participation rate of 5,85\%). Two sources were used in order to obtain the data regarding the best-performers companies operating in Romania: Top 500 Business Magazine (2016) and Top 1000 Piaţa Financiară (2017). The final sample consisted of 29 large companies (more than 250 employees) and 17 medium-size firms (between 50 and 249 employees). Two companies less than 50 employees were included in the medium-size category; one in which worked 34, and the other in which developed their activity 31 employees. 30 executives (e.g. President, CEO, General Manager) participated in the study. In addition to the executive suite, the analysis consisted in the answers provided by 10 middle managers (e.g. marketing manager), 5 firstline managers/operations managers (e.g. team leader), and one marketing specialist.

\subsection{Concepts operationalization}

First, we mention that we have investigated the APS of companies and organizations in our study depending to the four criteria/theoretical constructs developed in the theoretical part: 1) the type of partners within the portfolio - Alliance Portfolio Diversity (APD); 2) the Shaping Potential (SP); 3) the industry in which the company operates - Industry Life Cycle (ILC); 4) the current stage of organizational development - Organizational Life Cycle (OLC). These four criteria are the independent variables in our study. According to the theoretical framework they influence or cause the election of a specific APS. (The contingency factors as called in previous alliance studies.) [Hoffmann, 2007). Therefore, the dependent variable is the Alliance Portfolio Strategy (APS).

The first independent variable is 'Alliance Portfolio Diversity' (APD). The APD aims to capture the diversity and percentage of partners within the portfolio of alliances of companies. It is important to mention that APD was designed to be a firm-level variable. It means, it aims to capture the diversity 
of partners among all the alliances and partnerships of a focal company, among all focal firm's BUs. The variable APD was measured using a nominal scale with the following categories: 'suppliers', 'customers', 'competitors', 'complementors'. The managers were asked to group their partners in percentage from the entire portfolio. All the collaborators/partners of the company represented $100 \%$ (e.g. $25 \%$ are collaborations with firm's suppliers).

The second independent variable is 'Shaping Potential' (SP). According to the discussion within the theoretical part we define a company's SP such as the power to adapt the external environment to firm's needs, goals, and strategy. We measured the independent variable SP using an interval scale, with five categories, ranging from low to high shaping potential. Both components of a firm's SP MNC and Industry leader - were considered. The items MNC and Industry leader were measured using a nominal scale with dichotomic categories - yes or no.

The third independent variable is 'Industry Life Cycle' (ILC) and is defined such as a succession of stages through which a specific industry passes during its development starting with product/service conception, through growing and arriving to maturity. Most of existent studies in the management or marketing literature categorize the ILC based on four stages: birth, growth, maturity, or decline. Since is difficult to appreciate the current stage of development of a particular industry we measured the variable ILC using a nominal scale, with two dichotomous categories - younger or more mature/stable industry.

The fourth independent variable is 'Organizational Life Cycle' (OLC). OLC is defined such as the process of growth and development of a company from an entrepreneurial stage until the organization becomes a large corporation. Since all the companies in our study were categorized such as medium and large organizations, we measured the variable OLC using an ordinal scale with two categories - growth, respectively maturity/stability stage.

Finally, the dependent variable 'Alliance Portfolio Strategy' (APS) is defined such as an integrated set of actions aiming to design, implement and monitor a portfolio of alliances of a focal firm and the allocation of resources to accomplish firm's goals with alliances. We measured the variable APS using a nominal scale with three categories: adapting alliance portfolio strategy, shaping alliance portfolio strategy, stabilizing alliance portfolio strategy.

\section{DATA ANALYSIS AND DISCUSSION}

\subsection{Main patterns}

We start the data analysis with presenting the main patterns as resulted according to empirical data analysis. In Table 2 there is exhibited the detailed analysis. First, we can observe that there are 29 companies in their maturity/stability stage and 17 companies in their growth stage, according to OLC theory. In addition, 23 companies (representing 50\%) are subsidiaries of MNC in Romania and the other 23 are Romanian companies. We can summarize the main patterns of APS of companies in our study as follows: from the 46 companies which constitute the sample of companies in our study 17 companies designed and implemented an adapting alliance portfolio strategy, 16 companies designed and implemented a shaping alliance portfolio strategy, respectively 13 companies designed and implemented a stabilizing alliance portfolio strategy.

One can observe also that most of companies in our sample were characterized by a medium or high shaping potential (42 companies). Only in 4 cases the shaping potential was observed to be low or low-medium. In more concrete terms, the 42 companies were either a MNC or an Industry leader. In addition, most companies operate in more mature/stable industries (e.g. automotive, chemicals, engineering, transportation). Is the case of 41 companies. In addition, we have analyzed the answers provided by 5 companies operating in younger industries (e.g. IT, marketing solutions, sports betting). 
Next, in addition to illustrate what APS used the companies in our sample, we also aimed to investigate in detail, at 'molecular' level, the main patterns and characteristics of companies pursuing the specific alliance portfolio strategies discussed in this paper.

Table 2. Alliance Portfolio Strategy of companies in our sample

\begin{tabular}{|c|c|c|c|c|c|c|c|c|}
\hline \multirow{2}{*}{ 离 } & \multicolumn{4}{|c|}{ Alliance Portfolio Diversity } & \multirow{2}{*}{$\begin{array}{c}\text { Shaping } \\
\text { Potential } \\
\text { (MNC \& } \\
\text { Industry } \\
\text { leader) }\end{array}$} & \multirow{2}{*}{$\begin{array}{c}\text { Industry } \\
\text { Life } \\
\text { Cycle } \\
\text { (ILC) }\end{array}$} & \multirow{2}{*}{$\begin{array}{l}\text { Organizational } \\
\text { Life Cycle } \\
\text { (OLC) }\end{array}$} & \multirow{2}{*}{$\begin{array}{l}\text { Resulted } \\
\text { Alliance } \\
\text { Portfolio } \\
\text { Strategy }\end{array}$} \\
\hline & Suppliers & Customers & Competitors & Complementors & & & & \\
\hline 1. & 30 & 45 & 5 & 20 & high & $\begin{array}{l}\text { younger } \\
\text { industry }\end{array}$ & $\begin{array}{l}\text { maturity/ } \\
\text { stability }\end{array}$ & $\begin{array}{l}\text { Shaping } \\
\text { strategy }\end{array}$ \\
\hline 2. & 27 & 70 & 1 & 2 & $\begin{array}{l}\text { medium- } \\
\text { high }\end{array}$ & $\begin{array}{l}\text { mature } \\
\text { industry }\end{array}$ & $\begin{array}{l}\text { maturity/ } \\
\text { stability }\end{array}$ & $\begin{array}{l}\text { Stabilizing } \\
\text { strategy }\end{array}$ \\
\hline 3. & 50 & 50 & 0 & 0 & medium & $\begin{array}{l}\text { mature } \\
\text { industry }\end{array}$ & $\begin{array}{l}\text { maturity/ } \\
\text { stability }\end{array}$ & $\begin{array}{l}\text { Stabilizing } \\
\text { strategy }\end{array}$ \\
\hline 4. & 35 & 35 & 0 & 30 & medium & $\begin{array}{l}\text { mature } \\
\text { industry }\end{array}$ & $\begin{array}{l}\text { maturity/ } \\
\text { stability }\end{array}$ & $\begin{array}{l}\text { Adapting } \\
\text { strategy }\end{array}$ \\
\hline 5. & 30 & 58 & 2 & 10 & high & $\begin{array}{l}\text { mature } \\
\text { industry }\end{array}$ & $\begin{array}{l}\text { maturity/ } \\
\text { stability }\end{array}$ & $\begin{array}{l}\text { Shaping } \\
\text { strategy }\end{array}$ \\
\hline 6. & 20 & 60 & 15 & 5 & $\begin{array}{l}\text { medium- } \\
\text { high }\end{array}$ & $\begin{array}{l}\text { mature } \\
\text { industry }\end{array}$ & $\begin{array}{l}\text { maturity/ } \\
\text { stability }\end{array}$ & $\begin{array}{l}\text { Shaping } \\
\text { strategy }\end{array}$ \\
\hline 7. & 11 & 70 & 14 & 5 & $\begin{array}{l}\text { medium- } \\
\text { high }\end{array}$ & $\begin{array}{l}\text { mature } \\
\text { industry }\end{array}$ & $\begin{array}{l}\text { maturity/ } \\
\text { stability }\end{array}$ & $\begin{array}{l}\text { Shaping } \\
\text { strategy }\end{array}$ \\
\hline 8. & 58 & 40 & 2 & 0 & high & $\begin{array}{l}\text { mature } \\
\text { industry }\end{array}$ & $\begin{array}{l}\text { maturity/ } \\
\text { stability }\end{array}$ & $\begin{array}{l}\text { Stabilizing } \\
\text { strategy }\end{array}$ \\
\hline 9. & 55 & 40 & 1 & 4 & medium & $\begin{array}{l}\text { mature } \\
\text { industry }\end{array}$ & $\begin{array}{l}\text { maturity/ } \\
\text { stability }\end{array}$ & $\begin{array}{l}\text { Stabilizing } \\
\text { strategy }\end{array}$ \\
\hline 10. & - & - & - & - & high & $\begin{array}{l}\text { mature } \\
\text { industry }\end{array}$ & $\begin{array}{l}\text { maturity/ } \\
\text { stability }\end{array}$ & $\begin{array}{l}\text { Stabilizing } \\
\text { strategy }\end{array}$ \\
\hline 11. & 60 & 30 & 0 & 10 & high & $\begin{array}{l}\text { younger } \\
\text { industry }\end{array}$ & $\begin{array}{l}\text { maturity/ } \\
\text { stability }\end{array}$ & $\begin{array}{l}\text { Shaping } \\
\text { strategy }\end{array}$ \\
\hline 12. & 30 & 60 & 3 & 7 & high & $\begin{array}{l}\text { mature } \\
\text { industry }\end{array}$ & $\begin{array}{l}\text { maturity/ } \\
\text { stability }\end{array}$ & $\begin{array}{l}\text { Shaping } \\
\text { strategy }\end{array}$ \\
\hline 13. & 30 & 35 & 15 & 20 & $\begin{array}{l}\text { low } \\
\text { medium }\end{array}$ & $\begin{array}{l}\text { mature } \\
\text { industry }\end{array}$ & growth & $\begin{array}{l}\text { Adapting } \\
\text { strategy }\end{array}$ \\
\hline 14. & 70 & 20 & 10 & 0 & high & $\begin{array}{l}\text { younger } \\
\text { industry }\end{array}$ & $\begin{array}{l}\text { maturity/ } \\
\text { stability }\end{array}$ & $\begin{array}{l}\text { Shaping } \\
\text { strategy }\end{array}$ \\
\hline 15. & 20 & 80 & 0 & 0 & high & $\begin{array}{l}\text { mature } \\
\text { industry }\end{array}$ & $\begin{array}{l}\text { maturity/ } \\
\text { stability }\end{array}$ & $\begin{array}{l}\text { Stabilizing } \\
\text { strategy }\end{array}$ \\
\hline 16. & 20 & 70 & 5 & 5 & $\begin{array}{l}\text { low } \\
\text { medium }\end{array}$ & $\begin{array}{l}\text { mature } \\
\text { industry }\end{array}$ & growth & $\begin{array}{l}\text { Adapting } \\
\text { strategy }\end{array}$ \\
\hline 17. & 15 & 70 & 10 & 5 & high & $\begin{array}{l}\text { mature } \\
\text { industry }\end{array}$ & $\begin{array}{l}\text { maturity/ } \\
\text { stability }\end{array}$ & $\begin{array}{l}\text { Shaping } \\
\text { strategy }\end{array}$ \\
\hline 18. & 5 & 60 & 20 & 15 & $\begin{array}{l}\text { low- } \\
\text { medium }\end{array}$ & $\begin{array}{l}\text { mature } \\
\text { industry }\end{array}$ & growth & $\begin{array}{l}\text { Adapting } \\
\text { strategy }\end{array}$ \\
\hline 19. & 80 & 10 & 5 & 5 & medium & $\begin{array}{l}\text { mature } \\
\text { industry }\end{array}$ & growth & $\begin{array}{l}\text { Adapting } \\
\text { strategy }\end{array}$ \\
\hline 20. & 35 & 35 & 10 & 20 & medium & $\begin{array}{l}\text { mature } \\
\text { industry }\end{array}$ & $\begin{array}{l}\text { maturity/ } \\
\text { stability }\end{array}$ & $\begin{array}{l}\text { Adapting } \\
\text { strategy }\end{array}$ \\
\hline 21. & - & - & - & - & high & $\begin{array}{l}\text { mature } \\
\text { industry }\end{array}$ & $\begin{array}{l}\text { maturity/ } \\
\text { stability }\end{array}$ & $\begin{array}{l}\text { Shaping } \\
\text { strategy }\end{array}$ \\
\hline 22. & 20 & 60 & 10 & 10 & $\begin{array}{l}\text { medium- } \\
\text { high }\end{array}$ & $\begin{array}{l}\text { mature } \\
\text { industry }\end{array}$ & $\begin{array}{l}\text { maturity/ } \\
\text { stability }\end{array}$ & $\begin{array}{l}\text { Shaping } \\
\text { strategy }\end{array}$ \\
\hline 23. & 35 & 55 & 5 & 5 & $\begin{array}{l}\text { medium- } \\
\text { high }\end{array}$ & $\begin{array}{l}\text { mature } \\
\text { industry }\end{array}$ & $\begin{array}{l}\text { maturity/ } \\
\text { stability }\end{array}$ & $\begin{array}{l}\text { Stabilizing } \\
\text { strategy }\end{array}$ \\
\hline
\end{tabular}




\begin{tabular}{|c|c|c|c|c|c|c|c|c|}
\hline \multirow{2}{*}{ 离 } & \multicolumn{4}{|c|}{ Alliance Portfolio Diversity } & \multirow{2}{*}{$\begin{array}{c}\text { Shaping } \\
\text { Potential } \\
\text { (MNC \& } \\
\text { Industry } \\
\text { leader) }\end{array}$} & \multirow{2}{*}{$\begin{array}{c}\text { Industry } \\
\text { Life } \\
\text { Cycle } \\
\text { (ILC) }\end{array}$} & \multirow{2}{*}{$\begin{array}{l}\text { Organizational } \\
\text { Life Cycle } \\
\text { (OLC) }\end{array}$} & \multirow{2}{*}{$\begin{array}{l}\text { Resulted } \\
\text { Alliance } \\
\text { Portfolio } \\
\text { Strategy }\end{array}$} \\
\hline & Suppliers & Customers & Competitors & Complementors & & & & \\
\hline 24. & - & - & - & - & high & $\begin{array}{l}\text { mature } \\
\text { industry }\end{array}$ & $\begin{array}{l}\text { maturity/ } \\
\text { stability }\end{array}$ & $\begin{array}{l}\text { Shaping } \\
\text { strategy }\end{array}$ \\
\hline 25. & 0 & 0 & 0 & 100 & medium & $\begin{array}{l}\text { mature } \\
\text { industry }\end{array}$ & $\begin{array}{l}\text { maturity/ } \\
\text { stability }\end{array}$ & $\begin{array}{l}\text { Adapting } \\
\text { strategy }\end{array}$ \\
\hline 26. & 40 & 40 & 10 & 10 & medium & $\begin{array}{l}\text { mature } \\
\text { industry }\end{array}$ & $\begin{array}{l}\text { maturity/ } \\
\text { stability }\end{array}$ & $\begin{array}{l}\text { Adapting } \\
\text { strategy }\end{array}$ \\
\hline 27. & 60 & 30 & 0 & 10 & high & $\begin{array}{l}\text { mature } \\
\text { industry }\end{array}$ & growth & $\begin{array}{l}\text { Shaping } \\
\text { strategy }\end{array}$ \\
\hline 28. & 30 & 50 & 0 & 20 & $\begin{array}{l}\text { medium- } \\
\text { high }\end{array}$ & $\begin{array}{l}\text { mature } \\
\text { industry }\end{array}$ & growth & $\begin{array}{l}\text { Adapting } \\
\text { strategy }\end{array}$ \\
\hline 29. & 70 & 20 & 0 & 10 & medium & $\begin{array}{l}\text { mature } \\
\text { industry }\end{array}$ & $\begin{array}{l}\text { maturity/ } \\
\text { stability }\end{array}$ & $\begin{array}{l}\text { Adapting } \\
\text { strategy }\end{array}$ \\
\hline 30. & 30 & 40 & 10 & 20 & $\begin{array}{l}\text { medium- } \\
\text { high }\end{array}$ & $\begin{array}{l}\text { mature } \\
\text { industry }\end{array}$ & $\begin{array}{l}\text { maturity/ } \\
\text { stability }\end{array}$ & $\begin{array}{l}\text { Shaping } \\
\text { strategy }\end{array}$ \\
\hline 31. & 50 & 30 & 5 & 15 & medium & $\begin{array}{l}\text { mature } \\
\text { industry }\end{array}$ & $\begin{array}{l}\text { maturity/ } \\
\text { stability }\end{array}$ & $\begin{array}{l}\text { Adapting } \\
\text { strategy }\end{array}$ \\
\hline 32. & 5 & 95 & 0 & 0 & $\begin{array}{l}\text { medium } \\
\text { high }\end{array}$ & $\begin{array}{l}\text { mature } \\
\text { industry }\end{array}$ & growth & $\begin{array}{l}\text { Stabilizing } \\
\text { strategy }\end{array}$ \\
\hline 33. & 50 & 50 & 0 & 0 & $\begin{array}{l}\text { medium } \\
\text { high }\end{array}$ & $\begin{array}{l}\text { mature } \\
\text { industry }\end{array}$ & growth & $\begin{array}{l}\text { Stabilizing } \\
\text { strategy }\end{array}$ \\
\hline 34. & 20 & 60 & 10 & 10 & high & $\begin{array}{l}\text { younger } \\
\text { industry }\end{array}$ & $\begin{array}{l}\text { maturity/ } \\
\text { stability }\end{array}$ & $\begin{array}{l}\text { Shaping } \\
\text { strategy }\end{array}$ \\
\hline 35. & 25 & 45 & 15 & 15 & medium & $\begin{array}{l}\text { mature } \\
\text { industry }\end{array}$ & growth & $\begin{array}{l}\text { Adapting } \\
\text { strategy }\end{array}$ \\
\hline 36. & 33 & 33 & 33 & 1 & medium & $\begin{array}{l}\text { mature } \\
\text { industry }\end{array}$ & growth & $\begin{array}{l}\text { Adapting } \\
\text { strategy }\end{array}$ \\
\hline 37. & 30 & 60 & 5 & 5 & medium & $\begin{array}{l}\text { mature } \\
\text { industry }\end{array}$ & growth & $\begin{array}{l}\text { Adapting } \\
\text { strategy }\end{array}$ \\
\hline 38. & 40 & 40 & 0 & 20 & medium & $\begin{array}{l}\text { mature } \\
\text { industry }\end{array}$ & growth & $\begin{array}{l}\text { Adapting } \\
\text { strategy }\end{array}$ \\
\hline 39. & 20 & 80 & 5 & 5 & medium & $\begin{array}{l}\text { mature } \\
\text { industry }\end{array}$ & growth & $\begin{array}{l}\text { Adapting } \\
\text { strategy }\end{array}$ \\
\hline 40. & 50 & 50 & 0 & 0 & high & $\begin{array}{l}\text { mature } \\
\text { industry }\end{array}$ & growth & $\begin{array}{l}\text { Stabilizing } \\
\text { strategy }\end{array}$ \\
\hline 41. & 5 & 80 & 5 & 10 & high & $\begin{array}{l}\text { younger } \\
\text { industry }\end{array}$ & $\begin{array}{l}\text { maturity/ } \\
\text { stability }\end{array}$ & $\begin{array}{l}\text { Shaping } \\
\text { strategy }\end{array}$ \\
\hline 42. & 25 & 65 & 0 & 10 & medium & $\begin{array}{l}\text { mature } \\
\text { industry }\end{array}$ & $\begin{array}{l}\text { maturity/ } \\
\text { stability }\end{array}$ & $\begin{array}{l}\text { Stabilizing } \\
\text { strategy }\end{array}$ \\
\hline 43. & 50 & 20 & 10 & 20 & medium & $\begin{array}{l}\text { mature } \\
\text { industry }\end{array}$ & growth & $\begin{array}{l}\text { Adapting } \\
\text { strategy }\end{array}$ \\
\hline 44. & 50 & 50 & 0 & 0 & high & $\begin{array}{l}\text { mature } \\
\text { industry }\end{array}$ & growth & $\begin{array}{l}\text { Stabilizing } \\
\text { strategy }\end{array}$ \\
\hline 45. & 30 & 50 & 10 & 10 & high & $\begin{array}{l}\text { mature } \\
\text { industry }\end{array}$ & $\begin{array}{l}\text { maturity/ } \\
\text { stability }\end{array}$ & $\begin{array}{l}\text { Shaping } \\
\text { strategy }\end{array}$ \\
\hline 46. & 15 & 80 & 2 & 3 & $\begin{array}{l}\text { low } \\
\text { medium }\end{array}$ & $\begin{array}{l}\text { mature } \\
\text { industry }\end{array}$ & growth & $\begin{array}{l}\text { Stabilizing } \\
\text { strategy }\end{array}$ \\
\hline
\end{tabular}

Source: authors' own elaboration 


\subsection{Main patterns in detail}

The first pattern has to do with the companies which have designed and implemented an adapting alliance portfolio strategy. The data in our study indicate that these companies have developed multiple collaborations with firm's complementors and/or competitors, in addition to typical partnerships with firm's suppliers and customers. The average percentage of firm's collaborations with competitors and complementors is $8.11 \%$, respectively $18.58 \%$, from the entire portfolio of alliances. One can observe that there is a higher number of horizontal collaborations in comparison with the companies using either a shaping (7.42\%, respectively $9.42 \%)$ or stabilizing alliance portfolio strategy $(0.91 \%$, respectively $2 \%)$. From the total number of 17 companies which have been identified as having designed and implemented an adapting alliance portfolio strategy almost all are Romanian companies (16 companies) and almost three-quarters from them are growth stage firms (11 companies). The companies in this pattern, perhaps, are less powerful in term of resources and abilities endowment, and they are not necessarily the industry leaders, in comparison with the companies pursuing a shaping alliance portfolio strategy. Moreover, all the companies collaborating at the base of an adapting alliance portfolio strategy operate in a mature/stable industry.

The second pattern has to do with the companies which have designed a shaping alliance portfolio strategy. The data in our study indicate that almost all companies which have designed and implemented a shaping alliance portfolio strategy are subsidiaries of powerful MNC (12 companies from 16 companies which have implemented a shaping alliance portfolio strategy). One can observe that, in average, these companies have fewer horizontal collaborations (7.42\%, respectively $9.42 \%)$, in comparison with the companies which have designed and implemented an adapting alliance portfolio strategy by one side $(8.11 \%$, respectively $18.58 \%)$, and more horizontal collaborations in comparison with the companies adopting a stabilizing alliance portfolio strategy by the other side $(0.91 \%$, respectively $2 \%)$. We can observe also that all 5 companies which activate in younger industries in our study pertain to this pattern and that almost all companies are mature/stable organizations (15 companies from 16 companies using a shaping alliance portfolio strategy). The companies in this pattern are powerful companies in terms of resources and abilities endowment, they are industry leaders, and they strive to shape the external environment according to their strategy.

Finally, the third pattern has to do with the companies which have designed and implemented a stabilizing alliance portfolio strategy. One can observe that companies in this pattern have, in average, the fewest horizontal collaborations $(0.91 \%$, respectively $2 \%)$. In more concrete terms, one can observe that these companies almost do not collaborate with firm's competitors and/or complementors. In our sample there are several MNC ( 8 companies from the total of 13 companies using a stabilizing alliance portfolio strategy) which have a high shaping potential, but perhaps they use for Romania a stabilizing alliance portfolio strategy. In more concrete terms, they have designed and implemented in Romania an exploitation alliance strategy, aiming for productivity improvement. There is a clear indication that the focus of alliance activity is on productivity. In addition, one can observe that all companies in this pattern operate in mature/stable industries and more than half of them are in their maturity/stability stage (8 companies from 13 companies implementing a stabilizing alliance portfolio strategy).

In terms of internationality, one can observe that most MNC in our study resorted to a shaping alliance portfolio strategy (12 companies), followed by stabilizing ( 7 companies) and only one MNC appealed to an adapting alliance portfolio strategy. On the other hand, most Romanian companies (16 companies) used alliances as part of their strategy to adapt to their environment, thus resorting to an adapting alliance portfolio strategy. In addition, 4 Romanian companies implemented a shaping alliance portfolio strategy using alliances to shape their environment and 6 Romanian companies appealed to a stabilizing alliance portfolio strategy, using alliances to stabilize the environment in order to prevent future organizational change. 
Depending to firm's size, most medium size companies (11 companies) resorted to an adapting alliance portfolio strategy. In addition, only one medium size company used a shaping alliance portfolio strategy and 5 medium size companies designed and implemented a stabilizing alliance portfolio strategy. On the other hand, in the case of large companies the use of alliances was mostly for shaping the environment purposes (15 companies). An adapting alliance portfolio strategy was observed in the case of 6 large companies and a stabilizing alliance portfolio strategy in the case of 8 large companies.

Finally, all companies operating in younger industries used alliances to shape their environment according to company's strategy. On the other hand, in the case of companies operating in more mature/stable industries, 17 companies resorted to an adapting alliance portfolio strategy, 11 companies to a shaping alliance portfolio strategy, respectively 13 companies to a stabilizing alliance portfolio strategy. (See also Table 3).

Table 3. Main findings

\begin{tabular}{|c|c|c|c|}
\hline \multicolumn{2}{|r|}{ Variables } & Alliance Portfolio Strategy & $\begin{array}{c}\text { No. of } \\
\text { companies }\end{array}$ \\
\hline \multirow{3}{*}{\multicolumn{2}{|c|}{$\begin{array}{l}46 \text { best performers medium and large } \\
\text { companies }\end{array}$}} & Adapting Alliance Portfolio Strategy & 17 \\
\hline & & Shaping Alliance Portfolio Strategy & 16 \\
\hline & & Stabilizing Alliance Portfolio Strategy & 13 \\
\hline \multirow[t]{6}{*}{ Internationality } & \multirow[t]{3}{*}{$\mathrm{MNC}$} & Adapting Alliance Portfolio Strategy & 1 \\
\hline & & Shaping Alliance Portfolio Strategy & 12 \\
\hline & & Stabilizing Alliance Portfolio Strategy & 7 \\
\hline & \multirow[t]{3}{*}{ Romanian Company } & Adapting Alliance Portfolio Strategy & 16 \\
\hline & & Shaping Alliance Portfolio Strategy & 4 \\
\hline & & Stabilizing Alliance Portfolio Strategy & 6 \\
\hline \multirow[t]{6}{*}{ Firm Size } & \multirow[t]{3}{*}{ Medium Size Company } & Adapting Alliance Portfolio Strategy & 11 \\
\hline & & Shaping Alliance Portfolio Strategy & 1 \\
\hline & & Stabilizing Alliance Portfolio Strategy & 5 \\
\hline & \multirow[t]{3}{*}{ Large Size Company } & Adapting Alliance Portfolio Strategy & 6 \\
\hline & & Shaping Alliance Portfolio Strategy & 15 \\
\hline & & Stabilizing Alliance Portfolio Strategy & 8 \\
\hline \multirow[t]{6}{*}{ Industry } & \multirow{3}{*}{$\begin{array}{l}\text { Younger Industry } \\
\text { Company }\end{array}$} & Adapting Alliance Portfolio Strategy & - \\
\hline & & Shaping Alliance Portfolio Strategy & 5 \\
\hline & & Stabilizing Alliance Portfolio Strategy & - \\
\hline & \multirow{3}{*}{$\begin{array}{l}\text { Mature Industry } \\
\text { Company }\end{array}$} & Adapting Alliance Portfolio Strategy & 17 \\
\hline & & Shaping Alliance Portfolio Strategy & 11 \\
\hline & & Stabilizing Alliance Portfolio Strategy & 13 \\
\hline
\end{tabular}

Source: authors' own elaboration

\section{LIMITATIONS}

There are important limitations one should keep in mind at the point reading the present paper. There are limits resulting from the research methodology employed in this paper and there are theoretical limitations as well. First, regarding the research methodology the main goal was to identify the types of APS designed and implemented by best performers medium and large companies operating in Romania, based on data provided by companies' managers, according to a theoretical framework. Thus, in terms of generalizability, by one, the conclusions cannot be generalized in the case of entrepreneurial or small firms. For instance, the entrepreneurial and small firms do not have enough resources and abilities to implement a shaping alliance portfolio strategy. 
By two, the same conclusions perhaps cannot find support in the case of companies which are medium or low performers. In this paper, we have analyzed the data provided by best performers companies operating in Romania (top 1000). Since most companies, in general, have not enough resources and abilities their SP, for instance, is much lower, in comparison with the SP of companies in our sample. Therefore, the APS patterns of low or medium performers companies might look different since the APS are influenced or caused by the shaping potential.

In addition, this paper does not provide statistical evidence that the independent variables influence or cause the dependent variable. The main goal was to describe/illustrate the APS, according to a theoretical framework which was built upon the existent findings in the alliance management literature. Even though many of the independent variables were statistically investigated in the cited studies, our model consisting of the integration of the four independent variables influencing or causing the dependent variable, has not been tested using inferential statistics.

Second, regarding the theoretical limitations it is important to mention that the fact that the companies designing and implementing a stabilizing alliance portfolio strategy, for instance, are not preoccupied to collaborate to innovate does not mean, however, that they are not preoccupied to innovate at all. The data in our study only suggest that companies in this pattern do not collaborate/use alliances for innovation. More than that, since most of companies in this pattern have a high SP - they are powerful companies - probably they innovate alone or buy a company, if there is the case of accessing valuable resources and competences located outside company's boundaries. There are also other strategies which can be designed and implemented by companies (direct investments, mergers \& acquisitions, internationalization etc.) for both strategic directions innovation and productivity.

\section{CONCLUSIONS}

In this paper we have tried to investigate the APS designed and implemented by best performers medium and large companies operating in Romania. The results of our analysis indicate that best performers companies in Romania use quite different APS, even though they are all best performers companies (top 1000). The main findings suggest that most of medium size companies designed and implemented an adapting alliance portfolio strategy using alliances to better adapt their goods and services to existent markets, while the large firms appealed mostly to a shaping alliance portfolio strategy using alliances to shape the environment according to company's strategy. Moreover, the same story is true in the case of Romanian companies when compared with MNC. Romanian companies used alliances mostly to adapt while MNC resorted to alliances to shape the environment according to their needs. In terms of industry life cycle, all companies operating in a younger industry implemented a shaping alliance portfolio strategy, while for more mature industries there was observed a mix of patterns of alliance portfolio strategies adopted.

The results in this paper might be important for the business practice since might provide some useful guidance for companies at the point of designing a strategy for their portfolio of strategic alliances. This study might bring into the attention of managers the need to consider their company/BU strategic orientation (productivity and/or innovation), their company shaping potential, respectively the industry life cycle and organizational life cycle related to their company, at the point of formulating a strategy for their portfolio of alliances. In addition, managers might find in this paper a detailed description of each of the possible alliance portfolio strategies used by companies, together with their specific characteristics. For example, managers might find the optimal APD for each type of APS. Of course, there will be also other factors which need to be considered for designing an APS for a company, but even so the managers might find in this paper some useful guidance for designing a strategy for their portfolio of strategic alliances. 


\section{REFERENCES}

Albers, S., Wohlgezogen, F. \& Zajac, E. (2016). Strategic Alliance Structures: An Organization Design Perspective. Journal of Management, 42(3), 582-614.

Barnes, T., Raynor, S. \& Bacchus, J. (2012). A new typology of forms of international collaboration. Journal of Strategy and Management, 5(1), 81-102.

Barney., J., B. \& Clark, D., N. (2007). Resource-Based Theory: Creating and Sustaining Competitive Advantage. New York: Oxford University Press.

Brannen, M., Y. (1996). Ethnographic International Management Research. In Punnett, B. J. \& Shenkar, O. (Eds.). Handbook for International Management Research, pp.115-143, Cambridge, Blackwell.

Business Magazin (2016, October 24). Acestea sunt cele mai mari companii din România. Pe ce loc se află prima companie românească. Business Magazin. Retrieved from: https://www.businessmagazin.ro/actualitate/acestea-sunt-cele-mai-mari-companii-din-romania-pe-celoc-se-afla-prima-companie-romaneasca-15849928.

Chelcea, S. (2007). Metodologia cercetării sociologice. Metode cantitative și calitative. București, Editura Economică.

Collins, J. \& Riley, J. (2013). Alliance Portfolio Diversity and Firm Performance: Examining Moderators. Journal of Business and Management, 19(2), 35-50.

Daft, R. (2010). Understanding the theory and design of organizations. Mason, OH: South-Western Cengage Learning.

Das, T. \& Teng, B-S. (2000). A Resource-Based Theory of Strategic Alliances. Journal of Management, 26(1), 31-61.

David, F. (2007), (2013). Strategic Management. Concepts and Cases. NJ: Pearson/Prentice Hall.

de Leeuw, T., Lokshin, B. \& Duysters, G. (2014). Returns to alliance portfolio diversity: The relative effects of partner diversity on firm' s innovative performance and productivity. Journal of Business Research, 67, 1839-1849.

Dyer, J. \& Singh, H. (1998). The Relational View: Cooperative Strategy and Sources of Interorganizational Competitive Advantage. Academy of Management Review, 23(4), 660-679.

Dyer, J., Kale, P. \& Singh, H. (2001). How to Make Strategic Alliances Work. MIT Sloan Management Review, 4(2), 37-43.

Gulati, R. (1998). Alliances and Networks. Strategic Management Journal, 19, 293-317.

Gulati, R. \& Singh, H. (1998). The Architecture of Cooperation: Managing Coordination Costs and Appropriation Concerns in Strategic Alliances. Administrative Science Quarterly, 43(4), 781-814.

Hatfield, L., Pearce, J., Sleeth, R. \& Pitts, M. (1998). Toward validation of partner goal achievement as a measure of joint venture performance. Journal of Managerial Issues, 10(3), 355-372.

Heimeriks, K., Klijn, E. \& Reuer, J. (2009). Building Capabilities for Alliance Portfolios. Long Range Planning, 42, 96-114.

Hitt, M., Hoskisson, R. \& Ireland, D. (2007). Management of strategy. Concepts and Cases. Mason, OH: Thomson Higher Education.

Hoffmann, W. (2007). Strategies for Managing a Portfolio of Alliances. Strategic Management Journal, 28, $827-856$.

Hoffmann, W. (2005). How to Manage a Portfolio of Alliances. Long Range Planning, 38, 121-143.

Hwang, Y-S. \& Park, S., H. (2007). The Organizational Life Cycle as a Determinant of Strategic Alliance Tactics: Research Propositions. International Journal of Management, 24(3), 427-435.

Hwang, Y-S. \& Park, S. H. (2006). The evolution of alliance formation in biotech firms: An organisational life cycle framework. Management Dynamics, 15(4), 40-53.

Hynes, N. \& Wilson, J. (2012). Co-evolutionary dynamics in strategic alliances: The influence of the industry lifecycle. Technological Forecasting \& Social Change, 79, 1169- 1175.

Kale, P., Dyer, J. \& Singh, H. (2002). Alliance capability, stock market response, and long-term alliance success: the role of the alliance function. Strategic Management Journal, 23, 747-767.

Klijn, E., Reuer, J., Buckley, P. \& Glaister, K. (2010). Combinations of partners' joint ventures formation motives. European Business Review, 22(6), 576-590.

Lehene, C. (2020). Strategii de colaborare între companii. Contribuții privind creșterea performanțelor relaționate cu productivitatea și inovarea. Cluj-Napoca: Presa Universitară Clujeană. 
Lehene, C. \& Borza, A. (2017). An Exploratory Study on Alliance Competence and Alliance Portfolio Orientation in Romanian Firms. Management and Economics Review, 2(1), 47-67.

Lehene, C. \& Borza, A. (2016). The Influence of Organizational Life Cycle and Industry Life Cycle on Alliance Structure Choice. Proceedings of Managerial Challenges of the Contemporary Society, 9(1), 21-29.

Nielsen, B., B. \& Gudergan, S. (2012). Exploration and exploitation fit and performance in international strategic alliances. International Business Review, 21, 558-574.

Piața Financiară (2017, February 8). Top 1000 companii după cifra de afaceri pe 2015. Piața Financiară. Retrieved from: http://www.piatafinanciara.ro/top-1000-companii-dupa-cifra-de afaceri-pe-2015/.

Porter, M. (2003). The Economic Performance of Regions. Regional Studies, 37(6), 549-578.

Porter, M. (1998). Clusters and competition: new agendas for companies, governments, and institutions. In Porter, M. On Competition, pp. 197-287, Boston, MA: Harvard Business School Press.

Rice, J. \& Galvin, P. (2006). Alliance patterns during industry life cycle emergence: the case of Ericsson and Nokia. Technovation, 26, 384-395.

Rothaermel, F. \& Deeds, D. (2004). Exploration and exploitation alliances in biotechnology: A system of new product development. Strategic Management Journal, 25(3), 201-221.

Sarkar, M., B., Aulakh, P. \& Madhok, A. (2009). Process Capabilities and Value Generation in Alliance Portfolios. Organization Science, 20(3), 583-600.

Taylor, A. (2005). An operations perspective on strategic alliance success factors: An exploratory study of alliance managers in the software industry. International Journal of Operations \& Production Management, 25(5), 469-490.

Vapola, T., J., Paukku, M. \& Gabrielsson, M. (2010). Portfolio management of strategic alliances: An international business perspective. International Business Review, 19, 247-260.

Vyas, N., Shelburn, W. \& Rogers, D. (1995). An analysis of strategic alliances: forms, functions and framework. Journal of Business \& Industrial Marketing, 10(3), 47-60. 